\title{
Quartz Microtiter Plate in Homogeneous Assay Development
}

\author{
Insook Rhee Paeng, Eun Ah Lee, and Hee Seon Choi \\ Department of Chemistry, Seoul Homen's Chiversitv, Seoul 139-774, Korea \\ Received August 20,2003
}

Key Words : Homogeneous assay. Quartz microtiter plate. Biotin

Immunoassay has emerged as the most powerful tool with simplicity. specificity and sensitivity in the selective detection of various physiological biological and environmental substances at trace levels. ${ }^{1-3}$ Such methods can be classified as either heterogeneous or homogeneous. Heterogeneous arrangements are outstanding for low detection limits. but need a long reaction time compared to a homogeneous one. However. the homogeneous type assays are much faster because there is no need for the separation steps of free and bound label conjugates and additionally, are amenable to automation. 4.5

Enzyme-linked competitive binding methods ${ }^{6}$ are based on the competition between the unlabeled analyte and an enzyme-analyte conjugate for a limited number of binding sites. The homogeneous types. such as the enzyme-multiplied immunoassay teclunique (EMIT). rely on the ability of analyte molecules to reverse the inhibition of enzymeanaly'te conjugates induced by analy'te-specific binders. The EMIT method adapted to microtiter plate assay arrangements ${ }^{7}$ is rarely applied because of problems associated with non-specific adsorption of the binder and enzymelabeled reagents to the walls of the plates. Beyond potential non-specific adsorption problem. there is also difficulty in reliably assaying certain labeling enzymes with many existing microtiter plate readers. Enẓ̧me labels ${ }^{\delta}$ tỵpicallỵ used in the EMIT type homogeneous assays have been twosubstrate enzymes such as glucose-6-phosphate dehydrogenase $(\mathrm{G} 6 \mathrm{PDH})$ and malate dehydrogenase $(\mathrm{MDH})$ : the cataly tic activity of these dehydrogenase enzymes is measured by photometric detection of NADH at $340 \mathrm{~nm}$. However the enzyme. alkaline phosphatase (AKP), can be determined with p-nitrophenyl phosphate by measuring absorbance change at $405 \mathrm{~nm}$. Activity measurements at the visible region (405 nm) rather than the UV region (340 nm) could make it easier to adapt the microtiter plate reader format owing to less background absorbance from the plate materials in this wavelength region.

We adapted a quartz microtiter plate for homogeneous assay development so that it was possible to reduce the reaction volume and non-specific adsorption and to achieve a high sample throughput within a short time.

\section{Experimental Section}

Reagents and Apparatus. AKP from bovine intestinal

\footnotetext{
${ }^{*}$ To whom correspondence should be addressed. Tel: $+82-2-970-$ 5657, FAX: +82-2-970-5972, e-mail: ipaengassu.ac.ks
}

mucosa. N-hydroxỵ succinimidobiotin (NHS-biotin), avidin from egg white bovine serum albumin (BSA). p-nitrophenyl phosphate (p-NPP). d-biotin and all other reagents were purchased from Sigma (St. Louis. MO. USA). All chemicals used were of analytical reagent grade or better. and were used as received. All solutions were prepared using deionized water.

Enzyme activities were measured with a SPECTRAmax250 microtiter plate reader (Molecular Devices Co. Sunnyvale. CA. USA) at $405 \mathrm{~nm}$. A UV transparent quartz Microtiter plate (Molecular Devices Co. Sunnyyvale. CA. USA) was used.

Preparation of AKP-biotin Conjugates. AKP-biotin conjugate was prepared by reacting $\mathrm{AKP}$ with different amounts of NHS-biotin. The required amount of NHS-biotin dissolved in DMF was added to $500 \mu \mathrm{L}$ of coupling buffer containing a given amount of 200 units for AKP. The coupling buffer was $50 \mathrm{mM}$ sodium carbonate. $\mathrm{pH} 9.0$. The reaction was run for $24 \mathrm{hr}$ at $4{ }^{\circ} \mathrm{C}$ under stirring. After reaction, conjugate was dialyzed against $50 \mathrm{mM}$ Tri-HCl. $\mathrm{pH} 7.4$, and diluted to a final volume of $2.0 \mathrm{~mL}$ with the dialyssis buffer. The resulting enz̧me conjugates were characterized by their residual activities and percent inhibition induced by an excess amount of avidin. The assay buffer for AKP-biotin conjugates was $50 \mathrm{mM}$ sodium carbonate. $\mathrm{pH}$ 9.5 containing $0.01 \%(\mathrm{w} / \mathrm{v}) \mathrm{NaN}_{3 .} 0.01 \%(\mathrm{w} / \mathrm{v})$ gelatin. and $0.2 \%(\mathrm{w} / \mathrm{v}) \mathrm{BSA}$. Dilution of conjugates. binder. standards. and sample solutions were made using this assay buffer. All conjugates were kept at $4{ }^{\circ} \mathrm{C}$ until the additions of reagents for activity measurements.

Determination of Enzymatic Activity and Percentage Inhibition. The activity of AKP-biotin conjugates was determined by measuring the rate of appearance of $\mathrm{p}$ nitrophenol. measured by the change in absorbance at 405 nm per unit time. The assay involves addition of $50 \mu \mathrm{L}$ of $\mathrm{p}-$ NPP $(10 \mathrm{mM})$ and $50 \mu \mathrm{L}$ of appropriately diluted AKPbiotin conjugate to each well containing $150 \mu \mathrm{L}$ of assay buffer. For each assay, after mixing reagents. the absorbance of the mixture in each well was read over a 5 min period. In order to determine the percent inhibition value $50 \mu \mathrm{L}$ of the assay buffer was replaced by $50 \mu \mathrm{L}$ of avidin prepared in an assay buffer. In addition, conjugates were first incubated with avidin for 5 min before subsequent addition of substrate solution.

Dose-response Curves. For the dose-response curve for biotin. $50 \mu \mathrm{L}$ of the biotin standard was added to each well containing $50 \mu \mathrm{L}$ of avidin $(1.0 \mu \mathrm{g} / \mathrm{mL})$ and $50 \mu \mathrm{L}$ of assay 
buffer. After incubation for $5 \mathrm{~min}, 50 \mu \mathrm{L}$ of an AKP-biotin conjugate ( 1 : 100 dilutions) was added, and the inixture was incubated for a further $5 \mathrm{~min}$ period prior to activity measurements as outlined above.

\section{Results and Discussion}

Immunoassays come in many forms. They can range from test tubes (or microtiter plate) on large analyzers, to small devices, for qualitative or quantitative assays. A trend of immunoassay tests has been in fashion of using small disposable devices that are processed on a dedicated analyzer. However, commercial disposable microtiter plates can't be used in a homogeneous assay due to non-specific binding adsorption of the reagents to the walls of the plastic plates. Here, we employed a 96-wells quartz microtiter plate instead of plastic material to prevent non-specific adsorption, and investigated the feasibility of it in homogeneous assay development. Biotin was selected as a model analyte for this study and $\mathrm{AKJ}^{3}$ as a signal generator.

In order to perform the homogeneous assay for biotin, AKP'biotin conjugate was prepared. The particular conjugate, which prepared with a relatively high initial molar NHSbiotin: $\mathrm{AKP}^{2}$ ratio, therefore $2250: 1$, during the conjugation reaction, possesses a residual activity of $65 \%$ and is inhibited up to $76 \%$ by an excess of avidin, was used in all subsequent homogeneous type assays." Figure I illustrates the effects of changing the reaction time between the AKP-biotin conjugate and avidin. As can be seen, more than $90 \%$ of the maximum inhibition, induced upon binding of avidin to AKP-biotin, was achieved within $5 \mathrm{~min}$ of incubation. Association rates are much faster than those observed from the heterogeneous assay system employing an immobilized binding reagent. In subsequent experiments, incubation periods of $5 \mathrm{~min}$ (AKl'-biotin/avidin) were selected to gain a nearly maximum change in signal. Binder dilution studies were performed to determine the optimum concentration of binder for the homogeneous assay. Different amounts of avidin were incubated with a fixed amount of AKP-biotin.

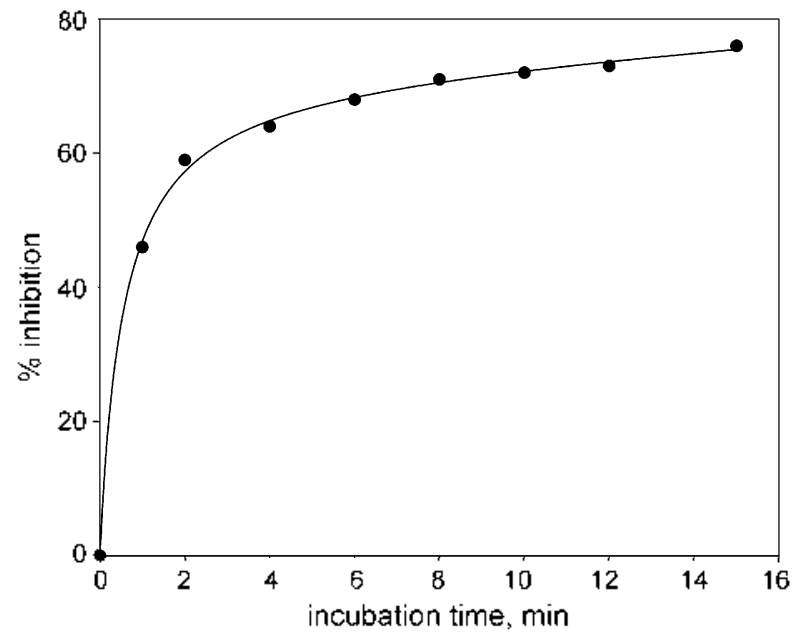

Figure 1. Leffect of varying the incubation time on the percent inhibition of 0.1 units AKP-biotin induced by $2.5 \mu \mathrm{g}$ avidin.

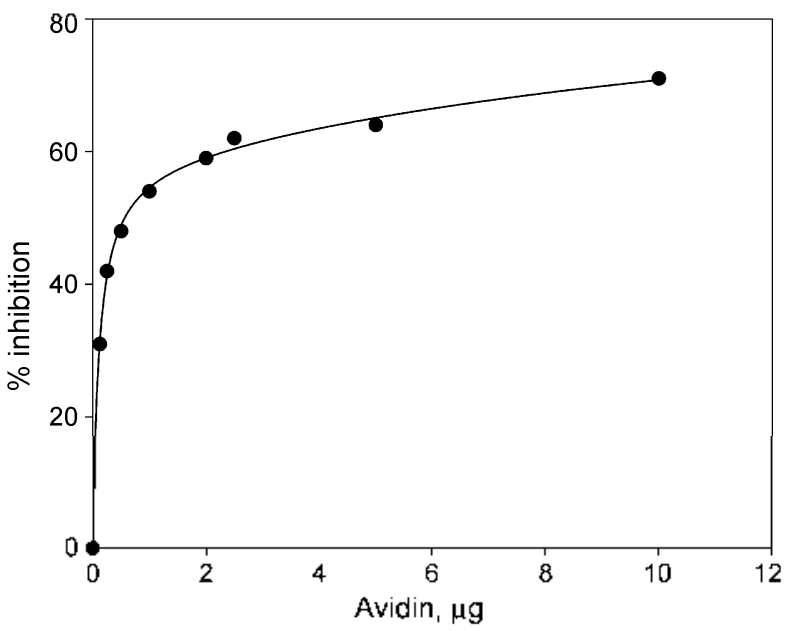

Figure 2. F.lfect of varying the levels of avidin on the intibition of AKP-biotin (0.1 units).

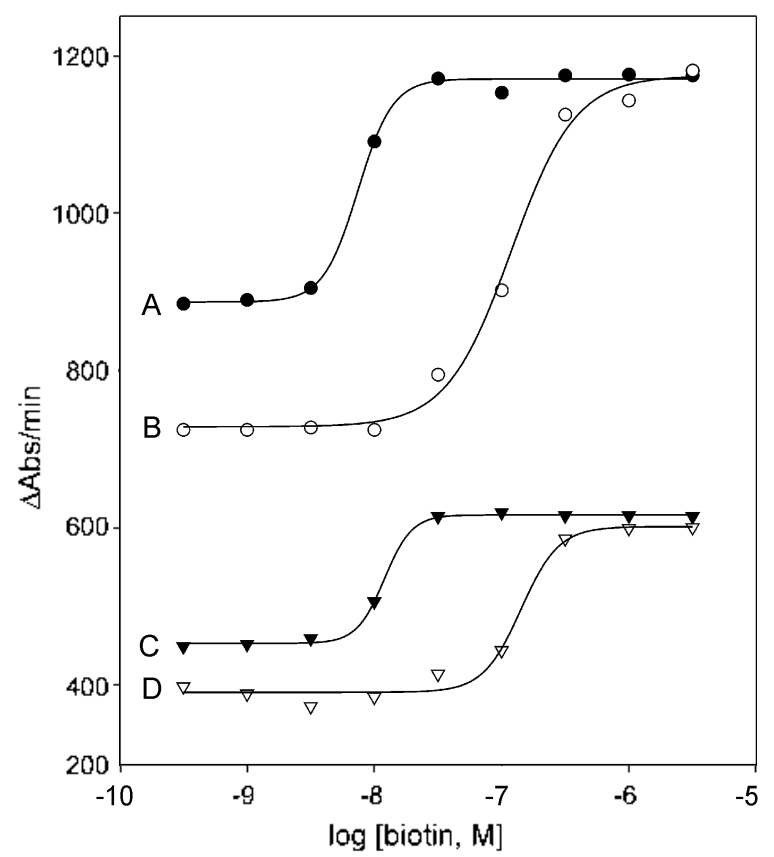

Figure 3. The effect of varyting avidin and $\triangle K P$-biotin concentrations on the dose-response curves obtained for biotin: (A) 0.1 units AK'P-biotin and $0.1 \mu \mathrm{g}$ avidin. (B) 0.1 units AKP-biotin and $0.2 \mu \mathrm{g}$ avidin. (C) 0.05 units AKP-biolin and $0.05 \mu \mathrm{g}$ avidin, and (D) 0.05 units $\Lambda K^{\prime}$-biotin and $0.2 \mu \mathrm{g}$ avidin.

As shown in Figure 2, the extent of inhibition increases as the amount of avidin is increased. For the AKP-biotin conjugates, the use of avidin in a range of $0.5-1.0 \mu \mathrm{g}$ provided more than $50 \%$ inhibition. Four different doseresponse curves for biotin were constructed by varying amounts of AKP-biotin and avidin in the assay mixture (Figure 3): A) 0.1 units and $0.1 \mu \mathrm{g}$. B) 0.05 units and $0.2 \mu \mathrm{g}$. C) 0.05 units and $0.05 \mu \mathrm{g}$, and D) 0.05 units and $0.2 \mu \mathrm{g}$. As can be seen, all of the curves are relatively steep over a narrow concentration range and anong them. Figure 3(A) represent the lowest detection limit. Figure 4 shows the dose-response curve for this work performed in a quartz 


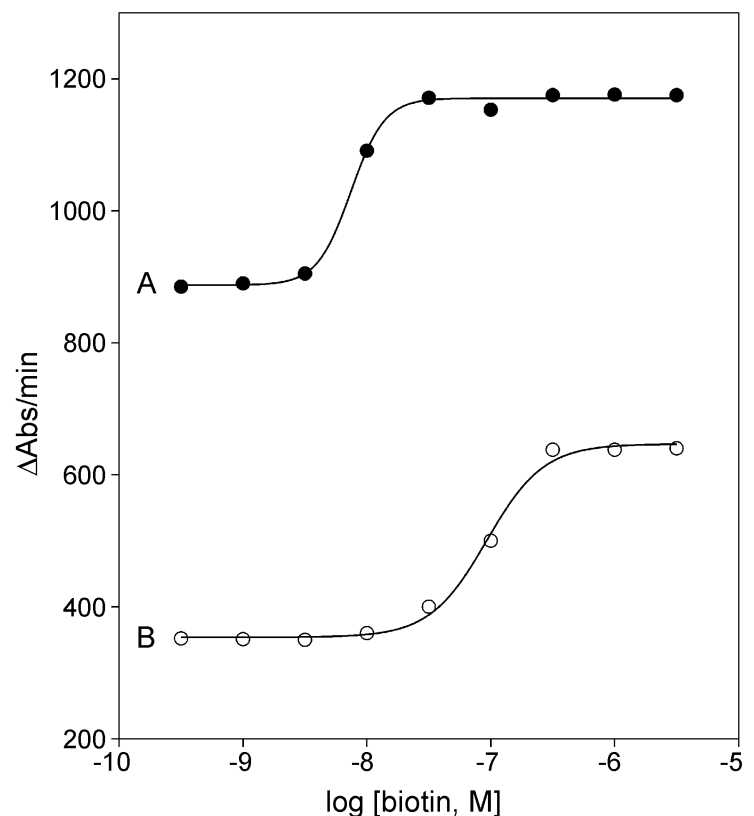

Figure 4. Dose-response curve for homogeneous biotin assay: (A) in quart\% microtiter plate I:MI'T $(0.1$ units $\mathrm{AKP}$-biolin and $0.1 \mathrm{\mu g}$ avidin). and (B) in tube $\mathrm{LMIJ}^{-0}(0.36$ units $\mathrm{AKP}$-biotin and $0.40 \mathrm{~kg}$ avidin).

plate and compared with a previous one. lable I summarized the assay conditions and results for biotin. As can be seen, the detection limit in the quartz microtiter plate EMl'] was found to be more than one-order lower (i.e., $3 \times 10^{-9} \mathrm{M}$ of biotin, $\mathrm{ED}_{50}=10^{-8} \mathrm{M}$ ) when compared to the common EMI'T (i.e., $1 \times 10^{-8} \mathrm{M}$ of biotin. $\mathrm{ED}_{50}=10^{-7} \mathrm{M}$ ). Here, the quartz microtiter plate could reduce the amounts of reagents and total reaction volume. Also, it is possible to minimize non-specific adsorption. Therefore, sample throughput has been made higher, turnaround time has been lowered, and, finally, detection limit could be minimized.

Thus, the quartz microtiter plate could be used successfully in homogeneous assay development.
Table I. Comparison of common Homogenteous Assay with 1 lomogeneous $A$ ssay adapted to a Quarty microtiter plate. for biotin assay

\begin{tabular}{|c|c|c|}
\hline & $\begin{array}{c}\text { Common I lomogeneous } \\
\text { Assays } \mathrm{s}^{\prime}\end{array}$ & This work \\
\hline AKP-biotin & 0.36 units tube & 0.1 unitswell \\
\hline Avidin & $0.40 \mu \mathrm{g} /$ lube & 0.1 ngiwell \\
\hline Incubation time & $10 \mathrm{~min}$ & $5 \min$ \\
\hline lotal volume & $1000 \mu \mathrm{l}$. & $250 \mu \mathrm{I}$. \\
\hline Throughput & 1 sämple/20 min & 96 samples 10 min \\
\hline Detection limit & $10^{-8} \mathrm{M}$ & $3 \times 10^{-3} \mathrm{M}$ \\
\hline F.I $)_{50}$ & $10^{-7} \mathrm{M}$ & $10^{-8} \mathrm{M}$ \\
\hline
\end{tabular}

Acknowledgement. 'This work was supported by a special research fund provided by Seoul Women's University. (Grant No. 20030146).

\section{References}

1. Nakamura. R. M.: Kasahara. Y. Hmmurochemict .4ssons and

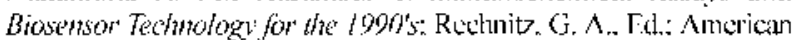
Sociely for Microbiology: Weshington. DC: liS.A. 1992.

2. Masseyel3, R. F.: Albert. W. [1. Wethods of Inmmological Analysis: Staines. N. A. Ed.: VCH: New York. U.S.A.. 1993: Vols. I and 2.

3. Immunotssen: Diannandis. E. P: Christopoulos. T. K.. Eds.: Academic Press: San Diceo. C. . 1996.

4. Rubenstein. K. J:.: Schneider. R. S.: Ullman. J:. 1: Biochen. Biophys. Res. Comm. 1972, 77.846.

5. Rowley. (j. L.: Rubenstein. K. E.: Huisjen. I.: Ulluan. E. F. .J. Biot. (hem. 1975. 231. 400.

6. Davics. C.: Wild. D.: Wilde. C. The Immanowsen Handbook: David. W. F:d.: Nature Publishing Ciroup: Linited Kingdom, 2001.

7. Kim. 13.: I3uckwalter, I. M.: Meyerhofl. M. I: Inat. Biodhen. 1994. 278.14

8. Kim. M. J.: Kim. H. J.: Kim. J. M.: Kim. B.: Han. S. H.: Cha. G. S. Anal, Biochem. 1995. 231, 400.

9. (a) Cho. H. C.: Lec. D. J.: Kim. S. Y.: Kim. J. H.: Paeng. I. R.: Chat (i, S. Anal. Sci. 1999, 15. 343. (b) Choi, M. II.: Kim, M. Il.: Cho. HI. C.: Kim. M. S.: l.ee. I: A.: Pateng. I. R.: Cha (j. S. Bull. Korew Chem. Soc 2001. 22.417. 